\title{
Sexuality and its Relation to Capitalism, Religion, and Madness in Allen Ginsberg's "Howl"
}

\author{
Jahin Kaiissar
}

Department of English and Humanities, Brac University, Dhaka, Bangladesh

\begin{abstract}
The mid-twentieth century American society saw the emergence of a literary movement known as the Beat Generation. The members of the Beat Generation were notorious for being nonconformists who broke social norms by engaging in various activities such as sexual experimentation. As a writer at the vanguard of the Beat Generation, Allen Ginsberg uses his poem "Howl” to introspect his own sexuality that goes against the conventional sexual norms of his society. This paper explores the portrayal of sexuality in "Howl." More specifically, it aims to investigate sexuality's connection to capitalism, religion, and madness through a close analysis of the poem. "Howl" reflects and transcends the time in which it was written because it portrays sexuality as a multifaceted and multilayered concept, affecting and being affected by various aspects of society. Sexuality, in the poem, cannot be discussed without shedding light on how it is influenced by capitalism and religion and how it is seen as the cause or effect of madness.
\end{abstract}

Keywords — Beat Generation, sexuality, capitalism, religion, madness.

\section{INTRODUCTION}

The Beat Generation was a literary movement that emerged in the mid-twentieth century as a reaction to the post-World War II American society. This era was marked by technological and industrial advancement which brought about spiritual emptiness and disillusionment. Members of the Beat Generation included the Beat writers who inspired counterculture by rejecting the conventional social values and challenging the academic norms for writing poetry and literature in general. They emphasized the use of authentic and spontaneous voice to capture and share specific moments or life experiences. Their refusal to censor their works is a proof of their frankness and candor. The content of their writings often involved topics considered to be taboo in mainstream American society such as mental illness, drug use, homosexuality, etc. The reason they focused on these subjects is that the Beat writers themselves were often described as being prolific travelers, drug users, alcoholics, jazz lovers, hedonists, and bohemians who were beaten up by the society at large, hence the name Beat Generation. Along with Jack Kerouac and William S. Burroughs, Allen Ginsberg was one of the prominent spokespeople for the Beat Generation.

Ginsberg's poem "Howl" serves as one of the founding texts of the Beat Generation. "Howl" is not just a work of social commentary or criticism but more specifically, it is a celebration of counterculture. Ginsberg challenges the conventional form in which a poem is written by writing it in a disjointed narrative-like way and emphasizing the poem's formlessness. He was a literary rebel who changed the scenery in the literary community by promoting the avant-garde. His use of profanity and sexual imagery is also a testament to his openness that defied social norms. Offending the mainstream public, the content of "Howl" aroused controversy for its use of coarse language and for its references to illicit drug use as well as heterosexual and homosexual sex. The poem's explicitness drew criticism and even provoked an obscenity trial against the poem's publisher, Lawrence Ferlinghetti, who was eventually acquitted. The fight against this censorship attests to the boldness and significance of "Howl." Sharing his personal confessions and revelations, Ginsberg uses "Howl" to celebrate perversity and nakedness of the soul, to give voice to the voiceless, and to criticize American society stifled with increasing materialism and consumerism. Therefore, both the form and content of the poem serves as an anguished rallying cry, a howl against repression and madness in the United States during the 1950 s. 
Divided into three parts, "Howl" deals with a wide variety of social issues. Part I focuses on the reason for how the destruction of "best minds" of Ginsberg's generation came to be and these best minds refer to other Beat writers or members of the Beat Generation. They are the people who are marginalized because of their unwillingness to adhere to mainstream beliefs and ideas. Due to how society suppresses them and stifles their lifestyle, they turn "mad" and hysterical. Part II of the poem gives all of the reasons he mentioned in the previous part a specific name which is "Moloch." As a god associated with child sacrifice, Moloch represents the mechanized and capitalistic society and the "best minds" are the children who are destroyed by him. Part III directly refers to Carl Solomon, Ginsberg's friend in a psychiatric hospital to whom the poem is dedicated. Solomon was one of the unfortunate "best minds" who suffered from undergoing shock treatments in a hospital. He was the manifestation of madness, the representation of Beat Generation.

Ginsberg did with "Howl" what many poets before him could not do. He succeeded in creating a counterculture manifesto and an authentic confession that denounced social attitudes and included powerful homoerotic images. He was able to make sexuality omnipresent in his poetry. Ginsberg's real-life love affair with Neal Cassady, a heterosexual inclined man, inspired him to use Cassady as his muse in the poem who travels to different places seeking sex from both men and women. In a way, Cassady in "Howl" portrays a romanticized hero of the Beat Generation who symbolizes sexual freedom. Thus, Ginsberg's liberal views are evident throughout the poem and many poets before him were unable to show the same openness that he did.

"Howl" highlights and rejects numerous social taboos and one which stands out the most when looking into Ginsberg's personal life is homosexuality. In "Howl," Ginsberg openly embraces homosexual male identity while simultaneously recognizing the internal tension of grappling with that very identity. By writing the poem and sharing it in the 1950s when homosexuality connoted mental illness or insanity, Ginsberg proves that he was ahead of his time. By including tormented figures like his own mother and Carl Solomon who were confined in asylums due to their "madness," Ginsberg also shows that many homosexuals and sexually "abnormal" individuals were also considered to be "mad" and thus suffered a similar fate. By providing a graphic description of sexual encounters with both men and women, Ginsberg voices his dissent and his refusal to accept the sexual identity imposed by religion and society at large. In the poem, he also shows how sexual experimentation was one way in which people explored their sexuality in an uninhibited way and found enlightenment. At that time, anything that went against heteronormativity and sex in the domestic nuclear family setting threatened the moral sensitivities of the "straight" nation. Therefore, Ginsberg celebrated sexual liberty by challenging that deeply entrenched status quo. He also revealed how sexuality was linked to other aspects of life in the 1950s, such as capitalism, religion, and madness.

Although Ginsberg seems to support homosexuality and sexual liberty, he also shows a contradicting stance at times by using self-deprecating language. Perhaps because his sexual fluidity makes him an outcast in American society, he feels ashamed and insecure about his orientation, causing him to never directly stating his sexual orientation in the poem. Hence, what seemed at first to be an unapologetic celebration of homosexuality may not be as unapologetic as it seems. Whether this is because of his fear of admitting his preference or not cannot be said for sure, but it can be said with certainty that Ginsberg had an identity crisis. Therefore, Ginsberg uses "Howl" to pour out his feelings in order to resolve this crisis and to come to terms with his own sexuality and identity. In doing this and in reading this poem out loud in public, Ginsberg becomes completely naked and vulnerable.

\section{LITERATURE REVIEW AND METHODOLOGY}

In Sigmund Freud's Three Essays on the Theory of Sexuality, the first essay called "The Sexual Aberrations" discusses what is considered to be abnormal sexual behavior. Freud states that homosexuality is a product of a psychological condition in early childhood. According to Freud, young boys who become later homosexuals or "inverts" often deal with the Oedipus complex which is associated with an intense fixation on their mothers (Freud, 2017, p. 16). After overcoming the Oedipus complex, "they identify themselves with the woman and take themselves as the sexual object; that is, proceeding on a narcissistic basis, they look for young men resembling themselves in persons whom they wish to love as their mother has loved them" (Freud, 2017, p. 16). Freud then proceeds to say that these homosexuals are not completely repelled by women or indifferent to the attractiveness and charms of women, but whatever excitement they feel with a woman is shifted to a male object. Therefore, Freud sees homosexuality as a developmental inhibition. Although many of his contemporaries believed homosexuality to be a sin or a 
vice, Freud was ahead of his time. This is shown when in a letter to the mother of a young homosexual man, he states that "homosexuality is neither a vice nor an illness" (Friedman \& Downey, 1998, p. 249). However, this is contradictory to what he said previously. He believes that homosexuality is the result of a psychological issue in childhood, but he also states that it is not an illness.

In The History of Sexuality, French philosopher Michel Foucault discusses the constructed nature of sexuality and how sexuality functions within a system of repression and constraints. He claims that up to the eighteenth century, "breaking the rules of marriage or seeking strange pleasures brought an equal measure of condemnation ... As to the courts, they could condemn homosexuality as well as infidelity, marriage without parental consent, or bestiality" (Foucault, 1990, p. 38). This means that homosexuality was criminalized for being a threat to the institution of marriage. In the nineteenth century, "homosexual became a personage, a past, a case history, and a childhood, in addition to being a type of life, a life form, and a morphology, with an indiscreet anatomy and possibly a mysterious physiology" (Foucault, 1990, p. 43). Therefore, according to Foucault, homosexuality first "emerged" in the nineteenth century, and during this time various observations were made to figure out whether homosexual tendencies are innate or culturally acquired. Either way, this emergence led to unfortunate views that considered homosexuality as a pathology. Thus, he shows how the discourse on sex and sexuality has always been repressed or demeaned. Foucault presents the bitter truth that any non-heterosexual sexual behavior furthered the normalizing processes that repressed sexual expression. In addition, instead of seeing sex as an act, Foucault was more focused on how sexuality is a staple to who we are and it becomes a part of how we define ourselves.

Epistemology of the Closet by a renowned queer theorist Eve Kosofsky Sedgwick discusses how "many of the major nodes of thought and knowledge in twentiethcentury Western culture as a whole are structured indeed, fractured - by a chronic, now endemic crisis of homo/heterosexual definition, indicatively male, dating from the end of the nineteenth century" (Sedgwick, 2008, p. 1). She argues that much of the attention, controversy, and demarcation that surrounds the issue of homosexuality since the late nineteenth century in both Europe and the United States has "been impelled by the distinctively indicative relation of homosexuality to wider mappings of secrecy and disclosure, and of the private and the public, that were and are critically problematical for the ... heterosexist culture at large" (Sedgwick, 2008, p. 71). In addition, she posits that the closet represents gay

ISSN: 2456-7620 oppression. To "come out" of the closet means to face hate and rejection from other members of society and to stay in the closet means to conceal one's true self. Therefore, like Foucault, Sedgwick presents the notion that homosexuality has always been historically subordinate to heterosexuality.

In his article "Homosexual Signs," Harold Beaver contends that "Homosexuality poses a uniquely peculiar challenge to cultural stability because it seems to threaten the genetic cycle itself and the whole elaborate coding of binary sexuality" (Beaver, 1981, p. 109). Deeply rooted in Western cultural tradition is the abhorrence of homosexual practices due to the fact that "it transgresses against breeding" (Beaver, 1981, p. 99). This means that homosexuality goes against the interests of the nation and is considered as a threat to the various institutions of capitalist nationhood such as marriage and family. However, Beaver also brings up an interesting notion that only partners in a marriage can undermine the institution of marriage by incest or adultery. Since homosexuals do not enter the contract of marriage, they are excluded from all social bonds.

According to American writer and activist Jeffrey Escoffier in "Homosexuality and the Sociological Imagination: The 1950s and 1960s," immediately after World War II, "homosexuality emerged into the American public consciousness with an unanticipated vigor" (Escoffier, 1997, p. 249). The issue of homosexuality became more controversial than ever before in America. The controversy was exacerbated by the fact that Senator Joseph McCarthy started a witch-hunt in the 1950s to fire homosexuals and communists from government jobs. Escoffier also states how "The threat of homosexuality to the postwar social order as well as the plight of homosexuals were extensively examined in novels, plays, and popular magazines" (Escoffier, 1997, p. 250). Moreover, he discusses how before the 1950s and 1960s, all discourses related to homosexuality were situated within the framework of psychoanalysis. Most of these discourses also stigmatized the sexual deviants by considering the deviancy to be a "psychological maladjustment" (Escoffier, 1997, p. 250).

Gore Vidal was among the first in the United States to write openly and seriously about homosexuality. Published in 1948, his novel The City and the Pillar shows his defiance towards the period in which being gay meant being effeminate, being powerless, and being an outcast (Vidal, 2005, p. 90). However, this defiance destroyed his political career (Vidal, 2005, p. 16). Vidal was adamant in his belief that being gay was a sexual act rather than a sexual identity. As a result, he insisted that most people were bisexual. Therefore, although he was involved in 
many sexual relationships with men and even wrote about homosexuality, he never openly identified himself as gay.

From the above discussion in the literature review, it can be said that societal attitudes toward homosexuality or "abnormal" sexual behavior have changed significantly over the past two centuries. There have been various debates regarding homosexuality such as whether it is genetic or caused by upbringing and environment. Although the cultural perception of homosexuality underwent a profound change after World War II, homosexuals continued to be belittled and oppressed by American society at large. All the writers mentioned in the literature review were ahead of their time. Although they have different views on homosexuality, none of them were homophobic despite the fact that many of their contemporaries were. Freud focused on understanding sexual aberrations from a psychoanalytic perspective while Escoffier criticized the idea of how homosexuality is considered to be the result of a psychological problem. On the other hand, Foucault and Sedgwick both dissected the concept of sexuality and how it has been conceptualized in history in different cultural contexts. They mainly emphasized how homosexuality has always been looked down upon as a threat to social institutions such as marriage and society in general. Beaver goes beyond this by saying that homosexuals are detached from production in a capitalist society and since they do not belong in any social bonds or contracts, they should not be judged or blamed for their sexuality. Vidal was included in the literature review because he openly wrote about homosexuality in the mid-twentieth century like Ginsberg. However, unlike Ginsberg, Vidal did not admit that he himself was a homosexual. Furthermore, unlike Foucault who believed that sex and sexuality are part of a person's identity, Vidal considered homosexuality to simply refer to the act of having sex with a person of the same sex.

This paper will be divided into three sections. The first section, "Capitalism and Sexuality," looks at how "Howl" portrays the division between homosexual subjectivity and national identity in a capitalistic society. By talking about sex that is not approved by society, Ginsberg demonstrates the detrimental effects of capitalism. The second section, "Religion and Sexuality," examines how Ginsberg demeans religion by describing sexual acts explicitly while simultaneously showing his openness and acceptance of various religions by referring to them. Finally, the last section, "Madness and Sexuality," focuses on how Ginsberg criticizes the way in which society considers any sexuality other than heterosexuality to be the sign of insanity.
To recapitulate, this paper will focus on how Ginsberg celebrates sexual expression and uses his poem to represent the forbidden voices of the marginalized sexual deviants. It will examine how sexuality is linked to capitalism, religion, and madness, and it will also explore how Ginsberg felt about his own sexuality.

\section{CAPITALISM AND SEXUALITY}

By swimming against the strong waves of social norms in capitalist America that promoted marginalization, Ginsberg was able to strengthen his own identity as a homosexual man. In the 1950s, when industrial capitalism was at its peak, American individuals' national identities were based on their conformity to their society. Consequently, their sexual identities were consumed and stifled by the oppressive capitalist machine. Thus, homosexuals were forced to the margins of society. Social inequality and the oppression of homosexuals, as well as other social, political, and economic issues, are deeply rooted in the capitalist society.

In "Howl," Ginsberg conveys the message that sexuality is a commodity of the prevailing capitalist system. The growth of the population is necessary in a capitalistic society to increase the number of proletariats or working class people to accumulate profit for the system. Since maximizing profit requires productive labor, a growing working class is crucial to the system. Furthermore, capitalism requires property holders such as workers who have managed to amass small sums of savings, and these property holders can pass their property to their children as an inheritance. This task requires having children. Hence, heterosexual relationships are vital to capitalist development. In "Howl" (2001), Ginsberg mentions how the best minds of his generation "lost their loveboys to the three old shrews of fate the one eyed shrew of the heterosexual dollar" (p. 51). This quote refers to how homosexual men in American society lose their lovers because they are often pressured to get married, settle down, have a well-paid job, and become a breadwinner for their family. When he refers to the "heterosexual dollar," Ginsberg shows how capitalism enforces heterosexuality and heteronormativity. Thus, he believes that capitalism is heterosexual, homogenous, and not individualistic. Then, he proceeds to say that the second one eyed shrew "winks out of the womb" and the third "does nothing but sit on her ass and snip the intellectual golden threads of the craftsman's loom" (Ginsberg, 2001, p. 51). Therefore, the second shrew represents the children that homosexual men are expected to provide for, and the final shrew represents the wives who are responsible for homemaking and are 
economically dependent on their husbands. Accusing the capitalistic society of being exclusively heterosexual, Ginsberg depicts a picture of the average American life in which individuals are enslaved by the dollar. Essentially, he is saying that capitalism drives people into creating heterosexual families out of sheer social expectations. He rejects the traditional heterosexual formula with one wife, two kids, a car, a steady income, etc. Moreover, by alluding to the Greek fates, Ginsberg could also be defending his sexual orientation by saying that his homosexuality is his fate and hence cannot be changed. Whatever the case, his aversion for capitalism is evident.

Furthermore, Ginsberg uses Moloch in the poem to portray how capitalism and sexuality are inexorably linked. Moloch, in the Old Testament, is a Canaanite god of fire to whom child sacrifices are made during a blood ritual. In "Howl," Moloch is the embodiment of the evils of capitalistic society since it suppresses sexuality and marginalizes sexual deviants. When he says "Cocksucker in Moloch! Lacklove and Manless in Moloch," Ginsberg insinuates his own marginalization in society as a result of his sexuality (Ginsberg, 2001, p. 54). Capitalism lacks love because it is fueled by hatred. It scorns individuality and free expression. As children sacrificed to Moloch, homosexuals in America were trapped in a suffocating and oppressive system. They were forced to sacrifice their thoughts and beliefs for the sake of the industrial machine. As victims of Moloch, Ginsberg and his circle of friends rejected the notion of sexual conformity that was imposed on them and began a discourse on sexuality. Sex in midtwentieth century America is largely political as it deals with discipline and control of appetite and body. Sex was considered only as a means of reproducing and nothing else. By releasing their repressed sexual hunger, members of the Beat Generation deviated from the established order of sexual behavior and embraced sex that is free from politics. They wanted to consider sex not as a means of reproduction but as an enjoyable and pleasing experience in itself. By having short-lived relationships, engaging in intercourse with multiples partners of both sexes, and doing it in public space, they supported a hedonistic culture marked by promiscuity and decadence. They relished in engaging in a homosexual, bisexual, or pansexual sex or relationship. Thus, Ginsberg tries to denounce capitalism by dispelling the negative stigma associated with sexual fluidity. In a capitalist society, the bourgeoisie controls the economy and the political power and mercilessly exploits the labor of the proletariat. In "Howl," the jazz musicians, drug addicts, alcoholics, bohemians, and homosexuals, while not always proletarian, are nonetheless identified as members of the oppressed and exploited classes. Thus, these people sought social and political revolution. Moreover, by saying "Moloch in whom I am a consciousness without a body," Ginsberg describes his loss of sexual identity (Ginsberg, 2001, p. 55). Therefore, he conveys the message that sexuality is vital to selfhood.

Consumerism, one of the defining factors of capitalism, can also be linked to sexuality. The capitalist system disseminated the belief that because a person's neighbors had things like television, microwave, or car, it was that person's obligation to purchase those things. The previous "I think, therefore I exist" mentality has transformed into "I purchase, therefore I exist" mentality. Because everyone was infatuated with over-consuming the same mass-produced products, Ginsberg and the other members of the Beat Generation believed that this consumer culture was enforcing conformity, rejecting individualism, and ostracizing anyone who did not follow the status quo. The best minds' dissatisfaction with the consumerist American society caused them to attempt suicide as they "cut their wrists three times successively unsuccessfully" or "jumped off the Brooklyn Bridge this actually happened and walked away unknown and forgotten" (Ginsberg, 2001, p. 52). When suicide attempts failed, they often turned to drugs or sex. When it came to sex, the best minds always experimented as they had sex with multiple partners of the opposite sex or the same sex. This shows that even though the Beats rejected consumer culture, they were influenced by it immensely. To put this into perspective, it can be said that consumerism mainly deals with commodification and with purchasing goods for pleasure. Thus, the Beats also followed this ideology of buying or choosing something and discarding it after they made use of it. Instead of material goods, what they "bought" or chose was sex. As homosexual, bisexual, or pansexual outsiders to the status quo, they slept with multiple partners solely for the sake of pleasure. After they achieved pleasure, they moved on to the next one. Therefore, they resisted the traditional notion of consumerism by shifting their focus from material goods to sex. The spiritual emptiness and emotional turmoil that resulted from capitalism and consumerism caused some people to seek human connection and sex. This proves that sexuality and American national identity are deeply entangled.

\section{RELIGION AND SEXUALITY}

Ginsberg's marginalization in American society was not only caused by his sexuality, but also by the fact that he grew up in a Jewish family and was raised as a secular Jew. He was a new kind of Jew who never limited 
himself to his parents' Jewish outlooks. While maintaining his Jewish identity, he explored different cultures and underwent many experiences which allowed him to become more open-minded and accepting of different views. Thus, religion plays a large role in Ginsberg's life and consequently, in the poem as well. "Howl" demonstrates how religion shapes people's attitudes about sexuality and prescribes what is considered to be acceptable and appropriate sexual behavior.

Throughout the poem, Ginsberg criticizes religion by referring to various religious or holy things such as angels and god in an obscene way. At the beginning of the first section, he refers to the best minds of his generation as "angelheaded hipsters," implying that they have halos and bestowing them a sacred feature (Ginsberg, 2001, p. 49). However, although he considers the best minds to be holy and sacred, the rest of the society would disagree. Therefore, he shows how everything is a matter of perspective. In addition, he claims that the madness that destroyed the best minds is a state of mind that is god-like. The "angelheaded hipsters" were driven to this holy state of mind by their society. Their madness is holy because it provided them with higher spiritual knowledge. Ginsberg also describes how he saw the best minds of his generation "dragged off the roof waving genitals and manuscripts ... let themselves be fucked in the ass by saintly motorcyclists and, screamed with joy ... blew and were blown by those human seraphim, the sailors, caresses of Atlantic and Caribbean love" (Ginsberg, 2001, p. 51). Here, Ginsberg's use of religious imagery when he says "saintly" motorcyclists and his portrayal of sailors as angelic beings contrast against the vulgarity, perverseness, and explicitness of the poem. Thus, motorcyclists and sailors, who were demeaned by American society at large in the 1950s, are portrayed as divine beings. Hence, Ginsberg criticizes religion for being homophobic and anti-erotic by explicitly describing underground homosexual practices.

Ginsberg also uses "Howl" to reveal the sexual deviants' vacillating mixture of acceptance and self-hatred or shame regarding their own sexuality. When saying "the blond and naked angel came to pierce them with a sword," the word "naked" proves that even angels who are the epitome of purity are associated with sex (Ginsberg, 2001, 51). Furthermore, the line, "who fell on their knees in hopeless cathedrals praying for each other's salvation and light and breasts," shows that the best minds sometimes seek forgiveness for their sins (Ginsberg, 2001, p. 53). Here, Ginsberg makes the readers think about what the Beat members are seeking forgiveness for. Perhaps they are seeking forgiveness for their non-normative sexualities and are asking God to save them from damnation. The use of the word "breasts" in the line also suggests that religion is hopelessly and inevitably linked to sex. In "Howl," Ginsberg shows the influence religion has over the Beat members and how religion can be toxic since it makes nonconformists feel guilty about the fact that they are different.

The fact that Ginsberg makes multiple religious references may also be interpreted as his attempt to portray the Beat generation's openness to religion and consequently, their openness to sexuality. When he says that the best minds "bared their brains to Heaven under the El and saw Mohammedan angels staggering on tenement roofs illuminated," Ginsberg uses the word "El" to refer to either the subway in New York or the name for God in Judaism and the word "Mohamedan" refers to the believers of Islam (Ginsberg, 2001, p. 49). Thus, by bringing in references from different religions, specifically Christianity, Judaism, and Islam, Ginsberg is indicating that he has no specific or direct religious preference. The fact that he does not ascribe to one religion proves his nonconformist and open-minded attitude. This is the opposite of his portrayal of American society as narrowminded and intolerant. Ginsberg and the rest of the Beat generation's openness to religion relates to their openness to sexuality. Due to the hostility of many religions in the mid-twentieth century against "abnormal" sexual behavior and relationships, many Beat members did not embrace any single religion. Rather, they embraced no beliefs or numerous beliefs. Thus, it is pertinent to point out that Ginsberg did not diminish the power of religion. He is simply trying to say that many non-heterosexual people do not find a place of acceptance and belonging in religion. Many religious people believed that they must help sexual deviants by steering them away from sexual immorality and they also condemned any sexual behavior outside the marriage of a man and a woman. Ginsberg is criticizing people who are blindly adhering to beliefs prescribed by their religion. It is ironic that many Beat members were accepting of various religions that did not accept them in return.

Moreover, by equating the "best minds" to Jesus Christ in the poem, Ginsberg portrays how the Beats are the heroes of American society. All the "best minds" including Cassady and Solomon are like Jesus Christ in the sense that the poem depicts them as meeting after death and reincarnating as jazz musicians. In addition, they asked the same question as Jesus "Eli eli lamma lamma sabacthani" which translates to "my God, my God, why have you forsaken me?" (Ginsberg, 2001, p. 54). The best minds were forced to suffer for their beliefs, even their sexual orientation. Because of their different stance on 
various things from drugs to sexuality, they were abandoned by and alienated from the mainstream society. Deserted by society and God, the Beats symbolize salvation. This idea is further portrayed in the poem when Ginsberg says to Carl Solomon, 'I'm with you in Rockland ... where you plot the Hebrew socialist revolution against the fascist national Golgotha" (Ginsberg, 2001, p. 56). By referring to the American government as the "fascist national Golgotha," Ginsberg is comparing his government's rejection of communism to that of the Roman authorities' act of crucifying Jesus Christ at Golgotha. The Roman government executed Jesus because they feared that Jesus, who preached and performed miracles, was becoming a more powerful and influential figure. Similarly, the American government feared that the spread of communism would lead to a revolution. As an anti-capitalist and a supporter of communism, Ginsberg depicts Solomon as a communist Jesus Christ who sacrifices himself to bring salvation to the American society. In the United States, leftist political activists were among the "earliest advocates of homosexual rights" (Escoffier, 1997, p. 106). Since the whole concept of communism is based on economic and social equality, people with different sexualities would also be treated equally from a communist perspective. Thus, the Beats like Solomon are advocates of equality. In advocating equality, they become both the victims and tragic saviors of American society.

Organized religion serves as a convenient tool by which the upper class elites keep the masses from revolting. Religion also allows people to escape from the struggles they face in a capitalistic society. However, in "Howl," Ginsberg portrays capitalism itself as a religion. Moloch, the embodiment of capitalism, becomes the deity of the mainstream culture in America. For most Americans, the pursuit and attainment of wealth were their true religious doctrine. When Ginsberg says "Moloch whose skyscrapers stand in the long streets like endless Jehovahs," he shows how the buildings and skyscrapers became the temples, their place of worship (Ginsberg, 2001, p. 54). This means that capitalism is also a religion for some people in the mid-twentieth century American society. Like religion, capitalism allows people to escape the troubles of their life. Skyscrapers became the new churches and money became the new bible. People sacrificed their human values in exchange for material gain. Thus, in "Howl," Ginsberg shows how capitalism became a religion and how this new religion has been used to disseminate negative ideas about unorthodox sexuality.

\section{MADNESS AND SEXUALITY}

Many Beat members suffered from mental breakdowns as a result of the repression of their true selves or as a result of social exclusion. Much of the activities that the Beat members were involved in -drinking, drug use, and sex with members of the same sex - were considered by the mainstream society to be the cause or the effect of insanity. Although they plunged themselves into these activities to escape the reality of the mid-twentieth century American society, they were misunderstood by the rest of the society as being insane. Ginsberg celebrated sexual freedom and he also celebrated madness because sexual freedom represented madness during his time. In the 1950s, American postwar psychoanalysts saw nonnormative sexuality as psychotic, neurotic, and insane. Thus, heteronormativity was promoted during this time. On the other hand, homosexuality was largely viewed as a mental illness or as a "clinical pathology that fell under the realm of medical expertise" (Chiang, 2010, p. 112). Therefore, homosexuals received harsh indictment from their society and they were treated as if they were insane.

In "Howl," whenever Ginsberg mentions psychiatric hospitals, he does not specifically mention sexuality. However, when reading the poem, one must take into account that in the 1950 s, homosexuality connoted insanity and vice versa. When mentioning "Pilgrim State's Rockland's and Greystone's foetid halls," Ginsberg is referring to psychiatric hospitals (Ginsberg, 2001, p. 53). Although the hospital is often considered to be a place of conformity with all of the patients wearing the same gowns, it becomes more like an erotic prison in "Howl." By describing characters who "threw potato salad at CCNY lecturers on Dadaism" and gave "harlequin speech of suicide," Ginsberg makes a caricature of the popular belief that homosexuals or sexually fluid people are criminally insane (Ginsberg, 2001, p. 53). The overexaggeration, humor, and self-parody shown in the lines allowed Ginsberg to belittle and criticize the repressive power of the American society that considers deviancy to be dangerous. Trapped in the prison-like hospital rooms, the patients find comfort and solace when they are "rocking and rolling in the midnight solitude-bench dolmen-realms of love," finding delight in the sexualities for which they are being confined and chastised (Ginsberg, 2001, p. 53). Ginsberg also compares bodies to stone and says that these stone bodies are "heavy as the moon" (Ginsberg, 2001, p. 53). Thus, he is saying that the patients are motionless like a stone. The fact that he compares bodies to stone can also be interpreted as the patients having no control over their bodies and as a result, having no control over their sexualities. Therefore, Ginsberg 
shows how societal expectations cause people to repress their sexualities and eventually drive them mad.

Furthermore, Ginsberg describes how patients in psychiatric hospitals often undergo intense and inhumane treatments that attempt to correct their abnormality or insanity, including their sexual deviancy. When Ginsberg talks about how the patients receive "the concrete void of insulin Metrazol electricity hydrotherapy psychotherapy occupational therapy pingpong \& amnesia," he is referring to the shock therapy which was administered to Solomon. Shock therapy is a medical treatment for mental illnesses that attempts to get the patient who is displaying "insane" thoughts to adopt new ways of thinking or new patterns of lifestyle. Thus, it tries to force the patient into acting in a more sane and proper manner. In addition, Ginsberg mentions how Solomon was physically restricted as he says "I'm with you in Rockland where you scream in a straightjacket that you're losing the game of the actual pingpong of the abyss" (Ginsberg, 2001, p. 56). Here, Ginsberg perhaps wanted to emphasize the word "straight" in "straightjacket" to imply that Solomon was physically and sexually restrained. Therefore, Ginsberg believes that shock therapy and many other treatments were a kind of torture that caused Solomon to become more insane instead of curing him. This idea of forcefully changing people's thinking and lifestyle can be related to how homosexuals also received intense shock treatments and faced lobotomy or castration in mental hospitals during this time. However, people cannot just suddenly decide to fight against sexual repression by performing differently, that is to say, by changing their sexuality like they change a shirt. Of course, they can pretend to be of different sexuality but their sexual preference does not change easily. Therefore, throughout the poem, there is the threat of the controlling and "normalizing" forces of the psychiatric hospital.

During his hospitalization, Ginsberg's sense of reality began to blur as he dealt with anxiety. This becomes especially apparent in the third part of the poem. In the final section of "Howl," Ginsberg is shown as being both distressed and excited by mental illness. He worries that he would end up like his mother who had been lobotomized. However, he also seems energized and inspired by the madness of other patients, specifically Solomon. At some points in the poem, Ginsberg even seems to be implying that insanity is synonymous with genius. By stating "I'm with you in Rockland where we hug and kiss the United States under our bedsheets the United States that coughs all night and won't let us sleep," Ginsberg directly mentions that he and Solomon had a sexual relationship (Ginsberg, 2001, p. 56). Thus, they are united in their homosexuality or "insanity" as incarcerated inmates. Although Ginsberg fears his sexuality or madness and its consequences, he feels comforted by the fact that he is not alone. By meeting Solomon who was more unhinged than him, Ginsberg realizes that unity is necessary for the Beat generation to rise up against the oppressive capitalist society. In Ginsberg's mind, psychiatric wards destroy genius by cloaking it as madness. Madness, therefore, is a gift and a curse.

\section{CONCLUSION}

The intersection between sexuality and capitalism, religion, and madness in "Howl" shows that the poem cannot be analyzed from just one lens. Every theme in the poem is interrelated. "Howl" depicts how the Beat members experimented with various facets of their identities. By exploring and experimenting with their sexuality, they showed how people are diverse in their desires and they attempted to break social taboos regarding sexuality. Although they were persecuted by mainstream American society, they remained steadfast in their belief that people should have sexual freedom. While "Howl" expresses many themes regarding capitalism, religion, and madness, the theme of sexuality is indispensable to the meaning and message of the poem as a whole because it can be linked to every other theme. First, the poem portrays how capitalism distorts individuals' sexuality. The growing number of homosexuals in the mid-twentieth century challenged the capitalist system because they had the possibilities of relationships and sex without procreation and the passing down of inheritance. Homosexuality or any other non-normative sexuality threatened the family and household system and in a broader sense, it threatened the moral fabric and national security. The connection between capitalism and sexuality raises the question of whether the fight to end oppression against homosexuals is synonymous with the fight to end capitalism. Secondly, Ginsberg weaves different religions together. In the poem, there is a collision between religion and sexuality. As Karl Marx states, "Religion is the sigh of the oppressed creature, the heart of a heartless world, and the soul of soulless conditions. It is the opium of the people" (Marx, 1844, p. 1). Unlike the twenty-first century when rampant and diverse sexuality permeates the popular culture, in the 1950s, followers of many religions believed "abnormal" sexuality to be a sort of cultural degradation. Finally, Ginsberg depicts the inhumanity of psychiatric hospitals that try to repress the sexualities of patients, causing them to become mad. Overall, the poem shows how instead of hiding and trembling in fear, the Beats fought by releasing everything that they were repressing. They howled. 
Not only does "Howl" reflect the time in which it was written, but it also transcends it. The spectrum of human sexual behavior and activity is wide and multifaceted and perhaps it is not even fixed to this date. Thus, issues regarding sexuality continue today. Certainly, progress has been made since the 1950s as the majority of the American society today supports gay marriages as well as many different sexualities. Yet, there are still countless problems within American society such as the increasing gulf between the upper class and the lower class or the growing number of suicides committed by homosexual youths due to bullying. In a world where people are being marginalized and excluded for being different, "Howl" will continue to be relevant. Therefore, the content of the poem continues to resonate with people in the twenty-first century.

\section{REFERENCES}

[1] Beaver, H. (1981). Homosexual Signs (In Memory of Roland Barthes). Critical Inquiry, 8(1), 99-119.

[2] Chiang, H. H. (2010). Sexuality and Gender in Cold War America: Social Experiences, Cultural Authorities, and the Roots of Political Change. Cold War and McCarthy Era: People and Perspectives, 111-128.

[3] Escoffier, J. (1997). Homosexuality and the Sociological Imagination: The 1950s and 1960s. A Queer World: The Center for Lesbian and Gay Studies Reader, 248-61.

[4] Foucault, M. (1990). The History of Sexuality: An Introduction, (R. Hurley, Trans.). Pantheon Books.

[5] Freud, S. (2017). Three Essays on the Theory of Sexuality: The 1905 Edition. Verso Books.

[6] Friedman, R. C., \& Downey, J. I. (1998). Psychoanalysis and the Model of Homosexuality as Psychopathology: A Historical Overview. American Journal of Psychoanalysis, 58(3), 249-270.

[7] Ginsberg, A. (2001). Selected Poems 1947-1995. Harper Collins.

[8] Sedgwick, E. K. (2008). Epistemology of the Closet. Univ of California Press.

[9] Marx, K. (1844). Contribution to the Critique of Hegel's Philosophy of Right. Deutsch-Französische Jahrbücher.

[10] Vidal, G. (2005). Conversations with Gore Vidal. Univ. Press of Mississippi. 